\title{
稆 介
}

\section{NOG 技術ノート No. 73}

\section{ノクセラー TS の低イオウ配合について}

(1)

1, ま え がき

通常のイオウ加硫による結合様式はポリサルファイド 結合が多く存在するために耐熱性はえがたいようです. ところが元素イオウ (Elimental sulfur) を使用せずに加 硫温度で分解して活性化イオウを供給するようなサルフ アー・ドナー加硫物は NOC 誌や本紙 NOC 技術ノー トでノクセラー $\mathbf{T T}^{1)}$ ， ノクセラー TRA ${ }^{2)}$ およびバル ノック $\mathbf{R}^{3)}$ についてすでに御報告しましたように耐老 化性の良い結果を与えて抢ります.

この方式による加硫は有効加硫方式 (Effieient Vulcanization System) とか単に E. V. 方式とか呼ばれ，“イ オウまたはイオウを供給するものがゴムの架橋に有効に 使用される方式”と定義されております.

この方式で加硫を行なうとイオウがゴムの架橋に有効 に使われるために架橋効率が高められ安定性の低いポリ サルファイド結合の存在割合が少ないといわれておりま す. T T単独加硫では主にモノサルファイド結合と多少

表 1 供試々料とその化学式

$$
\text { ノクセラー TS }
$$

Tetramethyl thiuram monosulfide

$$
\text { ノクセラー TT }
$$<smiles>CN(C)C(=S)SSC(=S)N(C)C</smiles>

Tetramethyl thiuram disulfide

$$
\text { ノクセラー DM }
$$

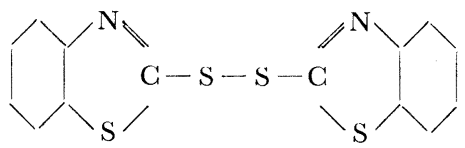

Dibenzothiazyl disulfide

\section{2. 実験方法および実験結果}

2.1 ムーニースコーチ $\left(\mathrm{t}_{5}\right)$ 試験（汹 1 )

奏験条件：JIS K 6300-1963に準拠 ML-1 (a) $21^{\circ} \mathrm{C}$
のジサルファイド結合とからなるといわれております。 有効加硫方式は通常のイオウ加硫より耐熱老化性, 常 温および高温における圧縮永久ヒズミがすぐれ，加硫厌 りの現象がなく高温加硫ができるなどの利点を有してお ります。

イオウ加硫においてゴムの架橋にイオウを有効に使用 するには通常のイオウ加硫よりイオウ量を少なくし多量 の加硫促進剤を用いればよいと思われます。またこの低 イオウ多量促進剤には $\mathrm{T} \mathrm{T}$ 単独加硫にみられるようなス コーチとブルーム性の問題がなくなるという長所があり ます。

今回は少量のイオウと多量のノクセラー TS 配合に よる加硫ゴムの諸物性を測定し, 通常のイオウ加硫（イ オウーノクセラー DM)， サルファー・ドナー加硫（ノ クセラー TT 単独) と加硫ゴムの物性面から比較検討 してみたので御報告します.なお NOG 誌37号 p. 3 11 御参照下さい.

表 2 基 礎 配 合

\begin{tabular}{lr}
\hline スモークドシート\#1 & 100 \\
亜 鉛 華 & 5 \\
ステアリン酸 & 3 \\
HAF ブラック & 40
\end{tabular}

(TS一低イオウ配合)

$\left\{\begin{array}{lrrrr}\text { イ ウ } & & 0.3 & 0.6 & 0.9 \\ \text { ノクセラー TS } & 0.7 & 1.0 & 1.5 & 2.0\end{array}\right.$ イオウ, TS との変量の全組合せについて行なった。

(1M-イオウ配合)

$\left\{\begin{array}{l}\text { オ ウ } \\ \text { ノクセラー } \mathbf{D M}\end{array}\right.$

( $\mathrm{TT}$ 単独配合)

ノクセラー TT

4. 0

イオウ量に対し TS を増量してもスコーチタイムに 差はあまりみられないが，TS 量に対しイオウを増量し ていくとスコーチタイムは相当にはやめられている。こ 


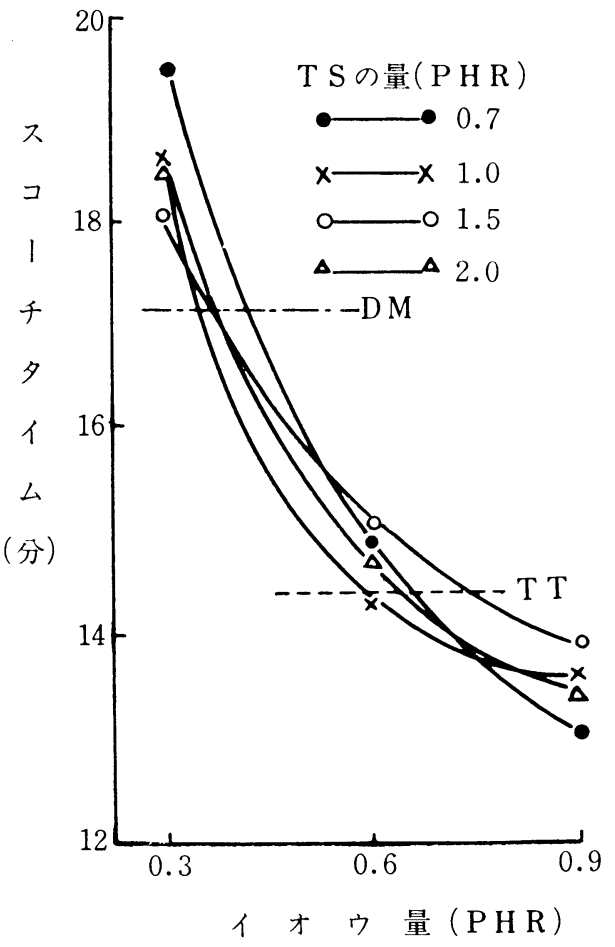

図 1 ムーニースコーチ夕イム $\left(\mathrm{t}_{5}\right)$

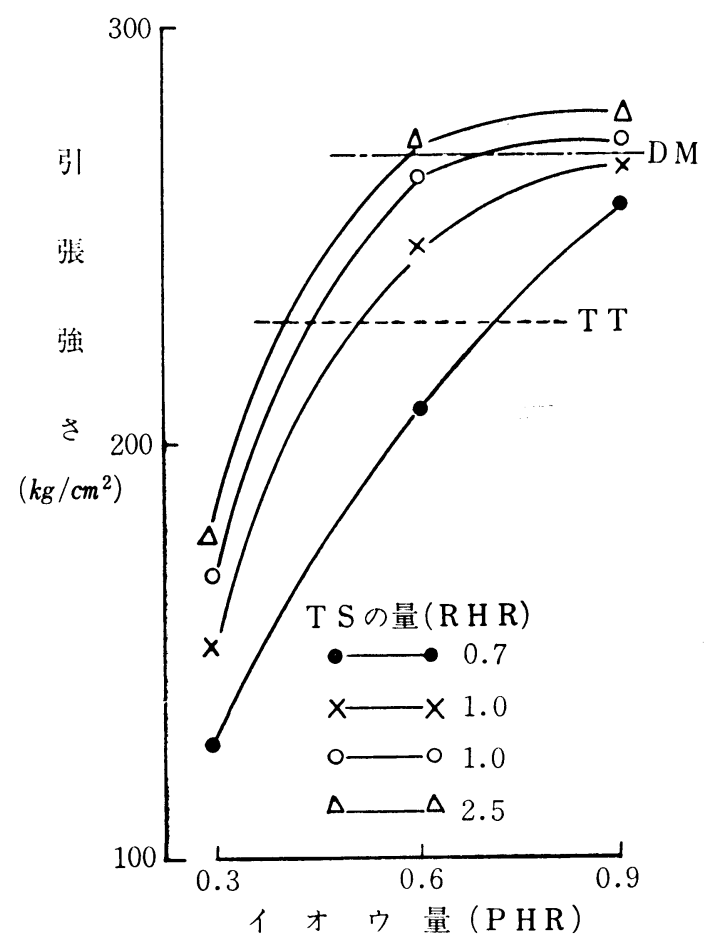

図2.引涨強さ・20分加硫

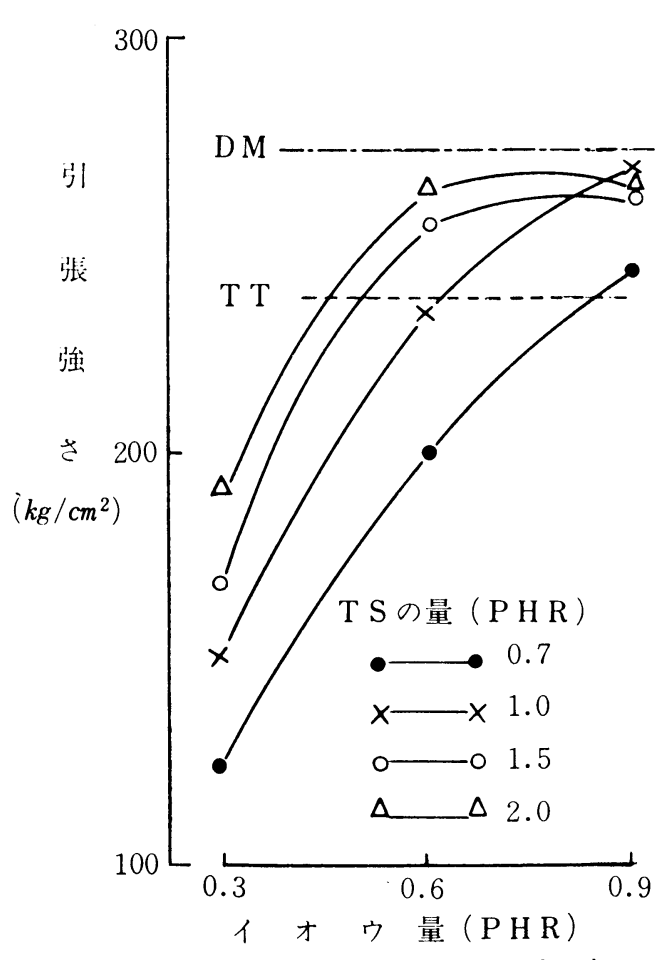

図3.引張強さ・40分加硫

れからスコーチタイムは TS よりもイオウにより左右 されるといえる. またイオウ量が 0.6 PHR 以下になる と TT よりもスコーチの危険性は少なくなっている.

\section{2 加 硫 試 験}

実験条件：JIS K 6301-1962 に準拠 プレス加硫温度：140 $\mathrm{C}$ 試験機：テンシロン 試験片：JIS 3 号ダンベル 測定時室温 : $23 \pm 1^{\circ} \mathrm{C}$

2.2.1 引張強市（図 2, 図 3 )

イオウと TS の量が共に増加すると引張強当も増大 する傾向を示めしている.

イオウ量が, 0.6 0.9 PHR, TS 量が $1.5 \sim 2.0$ PHR になると TT 加硫をしのぎ $\mathrm{DM}$ 加硫に匹敵する引張 強サを与えている。

40分加硫と20分加硫を比較してもあまり差はなく TS の低イオウ配合の引張強少は加硫時間によりあまり変化 していないことがわかる。

\section{参 考 文 献}

1) 2) NOC 誌31号 p. 13 48・32 号 p. $21 \sim 45$ NOG 技術ノート No. $58,59 ・$ No. $64 \sim 72$

3） NOC 誌 6 号 p. $5 \sim 20 \cdot 15$ 号 p. $5 \sim 8$ NOG 技術ノート No. 54,55 大内新興化学工業株式会社 